\title{
Teori Humanistik Kebutuhan Maslow dalam Pembelajaran Pendidikan Agama Islam Sekolah Dasar (Analisis Artikel Jurnal Sinta 2-6)
}

\author{
Rania Zulfi Fajriyah¹, Maemonah², Maryamah ${ }^{3}$ \\ 1,2Pascasarjana UIN Sunan Kalijaga Yogyakarta \\ ${ }^{3}$ UIN Raden Fatah Palembang \\ E-mail: 21204081012@student.uin-suka.ac.id, maimunah@uin-suka.ac.id, \\ maryamah_uin@radenfatah.ac.id
}

\begin{abstract}
Article Info
Article History

Received: 2021-11-15

Revised: 2021-11-28

Published: 2021-12-10

Abstract

Humanistic learning theory is a type of learning theory proposed by Abraham Maslow which emphasizes students to learn to study certain objects or materials related to their individual components. The following research aims to provide a description of the humanistic approach in teaching Islamic religious education in elementary schools. The use of the method in this research activity is the library research method.

Keywords:

Needs Theory;

Maslow; Referring to the results of his research that has been researched, he provides a

Approach;

Humanistic;

Education;

Islam. humanistic approach as an approach that provides assistance to students to like learning about the subject matter so that students' interest in learning becomes even better. Thus, its humanistic approach can be implied in PAI teaching in elementary schools. This humanistic very directs education to direct, develop and direct the basic interests possessed by students based on the three components, namely psychomotor, affective, and cognitive.
\end{abstract}

\begin{tabular}{l}
\hline Artikel Info \\
\hline Sejarah Artikel \\
Diterima: 2021-11-15 \\
Direvisi: 2021-11-28 \\
Dipublikasi: 2021-12-10
\end{tabular}
Abstrak
Teori belajar humanistik yakni jenis teori pembelajaran yang dikemukakan oleh Abraham Maslow yang memberi penekanan siswa agar menyukai tahapan pengajaran terhadap objek tertentu ataupun materi yang berkaitan dengan komponen kemaunisaannya. Penelitiannya berikut mempunyai tujuan dalam memberi pendeskripsian atas pendektatan humanistik di pengajaran Pendidikan Agama Islam pada Sekolah Dasar. Penggunaan metode dalam kegiatan meneliti ini yakni bermetodekan library research. Mengacu terhadap hasil penelitiannya yang sudah diteliti, memberi gambaran pendekatan humanistik sebagai suatu pendekatan yang memberikan bantuan siswa agar menyukai pembelajaran atas materi pelajarannya guna pengembangan minat belajar dari siswa menuju yang lebih bagus lagi. Sehingga, pendekatannya yang humanistik mampu diimplikasikan di pengajaran PAI dalam SD. Humanistik ini sangat mengarahkan ke pendidikan membimbing, mengambangkan dan mengarahkan pada minat dasar dimiliki oleh peserta didik berdasarkan dari ketiga komponen, yakni psikomotorik, afektif, serta kognitif.

\section{PENDAHULUAN}

Ketercapaian pada pengajaran Pendidikan Agama Islam di Sekolah Dasar sekarang selalu berkaitan terhadap berbagai permasalahan yang dijumpai, yang berhubungan langsung dengan pembeljaran atau tidak. Mayoritas tenaga pendidik Pendidikan Agama Islam saat ini maasih mempergunakan cara konvensional pada pengajaran Pendidikan Agama Islam contohnya melalui pemakaian papan tulis maupun buku maka siswanya memiliki semangat yang kurang untuk mengikuti pengajaran Pendidikan Agama Islam. Keberhasilan pembelajaran Pendidikan Agama Islam tidak diberi pengaruh dari media belajarnya saja, namun beragam hal yang berkaitan di dalam, misalnya model belajar, metodenya, dan pendekatannya. Sehingga, beragam komponen itu saling mempunyai ikatan.

Pendidikan ialah suatu ikatan humanisasi yang berasalkan dari pemikirannya paham humanistik. Hal tersebut berhubungan terhadap makna fundamental paham humanistik untuk pendidikan manusia. Sistem pendidikan Islam yang dirangkai berdasarkan pondasi beragam nilai kemanusiaan sejak terlahir selaras terhadap esensi keislaman yang merupakan suatu keagamaan yang humanistik. Islam menempatkan komponen kemanusiaan untuk arah kependidikannya. Edukasi serta tahapan pengajaran pada sekolah dasar dipersepsikan kurangnya demokratis. Terbatasnya tempat untuk peserta didik dalam pengembangan daya imajinasinya serta kreativitas yang mereka miliki melalui 
persepsinya. Padahal, kreativitas serta kemampuan kritis saat berpikiran yaitu modal terpenting untuk anak agar mampu menangani rintangan yang lebih kompetitif. (Arbayah, 2013)

Idealnya pembelajaran Pendidikan Agama Islam dapat memberi peningkatan kualitas serta efisiensi pada pengajaran melalui beragam pilihan, contohnya penggunaan beragam pendekatan yang selaras terhadap karakteristiknya pesera didik. Keberhasilan dalam pembelajaran Pendididkan Agama Islam bukan bergatung dengan fasilitas sekolah, meskipun sekolah tersebut hanya menyediakan fasilitas yang sederhana. Disamping itu sorang pendidik di tuntut agar ada keaktifan serta memiliki kreatifitas saat pengajaran supaya suatu aktivitas pembelajaran berhumanis mampu tercapai, pendekatan Humanistik ini menjadi acuan bagi tenaga pendidik Pendidikan Agama Islam untuk menyusun langkah pada proses pembelajaran, melalui pendekatan tersebut materi yang tidak mudah untuk dipahami dari siswa jadi terdapat kemudahan diberi tanggapan dari siswanya maka tujuan pengajaran mampu dicapai dengan maksimal. Pendekatan humanistik yang digunakan dalam Pembalajaran Agama Islam berupaya menjadikan pembelajaran yang memiliki arti serta pusatnya kepada siswa.

\section{METODE PENELITIAN}

Penelitian ini merupakan penelitian dengan library research yang sumbernya berasal dari artikel ilmiah, internet atau kepustakaan. Hasil penelitian ini menunjukkan pendekatan humanistic yang meenggambarkan pendekatan yang memberi bantuan siswanya agar menyukai materi pembelajaran guna pengembangan keminatan siswanya menuju lebih baik lagi, sumber utama data dalam penelitian ini diambil dari:

Tabel 1. Telaah Pustaka

\begin{tabular}{llcc}
\hline Penulis & Jurnal & Sinta & Tahun \\
\hline Aam Amalia & Edulab & 5 & 2019 \\
\hline Alaudin & Jurnal Pendidikan IQRA & 2 & 2015 \\
\hline Arbayah & $\begin{array}{l}\text { Dinamika Ilmu: Jurnal } \\
\text { Pendidikan }\end{array}$ & 2 & 2013 \\
\hline $\begin{array}{l}\text { Muhammad } \\
\text { Riyanton }\end{array}$ & Jurnal Lingua Idea & 4 & 2015 \\
\hline $\begin{array}{l}\text { Muhammad } \\
\text { Yasin }\end{array}$ & Jurnal An-Nur & 6 & 2017 \\
\hline $\begin{array}{l}\text { Henry Aditia } \\
\text { Rigianti }\end{array}$ & Elementary School & 4 & 2020 \\
\hline $\begin{array}{l}\text { S. Inikah } \\
\text { Jurnal Konseling Religi: }\end{array}$ & $\begin{array}{l}\text { Bimbingan Konseling } \\
\text { Islam }\end{array}$ & 2 & 2015 \\
\hline
\end{tabular}

Teknik dalam menganalisis yang dipergunakan yakni menganalisis isi, yan dilaksanakan melalui perbandingan, pemilihan, analisis, serta penciptaan atas kesimpulan dari beragam definisi itu maka bisa didapatkan suatu data yang berelevan (Yuliandri, 2017).

\section{HASIL DAN PEMBAHASAN}

Dari hasil analisis dapat dilihat dari ketujuh artikel jurnal yang dianalisis telah menerapkan teori kebutuhan maslow dalam proses pembelajaran. Teori belajar humanistik adalah teori yang yang memfasilitasi siswa agar menyukai dalam proses pembelajaran pada objek tertentu ataupun materi yang diterapkan guru berkaitan terhadap komponen kemanusiaan. (Alaudin, 2015). Tujuan menurut aliran humanistik yaitu agar memanusiakan manusia. Proses pembelajaran dapat berhasil apabila siswa paham akan lingkungannya maupun pribadinya sendiri. (Arbayah, 2013). Maka dari itu, sekolah dalam pengakuan teori pembelajaran humanistik bisa mengakkomodasi semua keburuhan dalam proses pendidikan. Dikarenakan pendidikan humanistic memiliki tafsiran merupakan suatu pendidikan yang diberi arah dalam seluruh keperluan di kependidikan, tidak sekadar memiliki orientasi kepada humanisme siswanya namun pula pada tenaga pendidik.(Riyanton, 2015).

Penerapan teori humanistik pada proses pembelajaran hendaknya tenaga pendidik dapat mengarahkan peserta didik dalam berpikir induktif, memprioritaskan praktik serta menguitamakan pentingnya kontribusi siswa pada tahapan pengajaran. Hal itu pun bisa dipraktekkan melalui berdiskusi maka siswa bisa menyampaikan hal yang ada dalalam pemikirannya di hadapan siswa yang lain. Proses pembelajaran menurut teori humanistik memilki sifat dalam mengembangkan pribadi, rohani, berperilaku, dan paham akan kejadian dalam masyarakat. Tolak ukur dalam keberhasilan pengaplikasian itu yakni siswa merasa memiliki semangat dan aman pada tahapan pengajaran, dan terdapatnya perubahan yang jauh lebih baik dari cara berpikiran, berperilaku, serta mengendalikan dirinya. (Suprihatin, 2017).

Maslow berpendapat pada dasarnya yakni pengembangan motivasi. Didalamnya ada tuntutan peran pendidik agar mampu memberi peningkatan semangat peserta didik dalam mengaktuallisasikan diri. Pada kegiatan pembelajaran dijumpai proses-proses pengembangan motivasi, pemahaman, keinginan untuk menjadi lebih baik, kecenderungannya akan hal yang baik, bisa bertanggungjawab, dan dapat paham beragam aktivitas pembelajaran. Berdas- 
arkan pendidikan yang berhumanis, tahapan pembelajaran mencakup mencocokan informasi maupun menghafal yang bisa memberi dorongan pada sistem belajar yang semula tidak ada keaktifan. Tahapan pembelajaran merupakan kegiatan manusiawi, para peserta didik dilatih untuk terus belajar di keadaan yang membuat senang namun tidak merasa terpaksa.

Pembelajaran Pendidikan Agama Islam pada Sekolah Dasar melalui pemanfaatan pendekatan humanistic ini perlu mengutamakan komponen intelektualnya, emosional, ketuhanan / spiritual peserta didik dan mampu menyajikan fasilitasnya serta peluang dalam menampilkan dirinya, pengalaman, opini, serta kerjasamanya, dalam merealisasikan aspek dalam pendekatan humanis ini memberi saran pada ketiga hal pada aktivitas pengajaran PAI di SD:

1. Guru membimbing dan menjelaskan mengenai manfaat belajar PAI serta melatih siswanya supaya ada kemampuan mempraktekannya dalam kehidupan sehari-hari.

2. Mengimplemantasikan teknik bermain peran, serta praktek yang bermaksud melatih mereka agar memahami materi PAI pada proses pembelajaran.

3. Memberikan contoh akhlak yang baik kepada peserta didiknya.

\section{A. Biografi Abraham Maslow}

Individu tokoh psikologi lahir di Amerika yang begitu terkenal, tempat lahirnya yakni di Brooklyn saat 1 April 1908 bernama lengkap Abraham Harold Maslow. Orang tua Maslow asalnya dari kota imigran Rusia yang tidak memiliki pendiidkan baik pada umumnya. Ayahnya sangat memiliki harapan agar anaknya itu memperoleh pendidikan yang berkualitas serta memberi dorongan agar mampu mengakses di bidang pendidikan pada suatu hari nanti, Abraham Harold Maslow (1908- 1970) merupakan salah satu dari tokoh Amerika dalam bidang psikologi. Maslow yaitu guru besar di University Alliant International, University Brandeis, Brooklyn College, New School for Social Research, dan University Columbia. Maslow sangat mengutamakan penting untuk fokus terhadap kualitasnya makhluk yang positif.

Ketika tamat dari sekolah menengah, Maslow melanjutkan studi hukum di City College of New York (CCNY). Setelah melaksanakan kuliah semester tiga, di tahun 1927 Maslow pindah ke kota Cornell dan setelah itu balik lagi ke kota New York.
Ketika sudah lulus studi pada City College, Maslow melanjutkan sekolahnya lagi di University of Wisconsin agar memahami ilmu psikologi, saat 1928, Maslow menikahi dengan saudara sepersepupuannya Bertha Goodman yang menjalankan pendidikan pada tingkat sekolah menengah ketika itu. dirinya dan istrinya pada saat itu memanfaatkan watku bekerjanya bersama Harry Harlow dalam melakukan riset terkait monyet.

Maslow telah menyelesaikan pendidikan sarjananya (BA) di tahun 1930, pendidikan Magisternya di 1931 dan pendidikan Doktor (Ph.D) nya di 1934, ketiga pendidikannya itu mengenai bidang ilmu psikologi di Wisconsin University. Satu tahun setelah menyelesaikan studinya, Maslow kembali lagi ke kota New York dengan maksud agar melaksanakan kerja sama dengan E.L. Trorndike di Columbia University, yang mana Maslow memiliki ketertarikan tinggi dalam melaksanakan risetnya terkait seksualitas dalam diri manusia, Abraham Harold Maslow menjadi tenaga pengajar di sekolah Brooklyn College. Selama dia mengajar mulai berkaitan terhadap beragam tokohtokoh ilmuan dan intelektual di Eropa dan Amerika, terkhususnya ketika itu yakni Adler, Fromm, Horney, dan pula ada beragam pakar ilmuan psikologi Gestalt dan psikologi analisis Sigmund Freud serta para muridnya. Maslow merupakan ketua prodi psikologi pada Brandeis saat 1951 sampai 1969. Ketika itu, Maslow bertemu bersama ilmuan Kurt Goldstein yang mempunyai gagasan self- actualization yang begitu fenomenal melalui buku miliknya, The Organisme saat 1934. Sekarang ini, dirinya mengawali perjuangan dalam keilmuan psikologi humanistik sebagai hal paling penitng kepada teori ini.

Lalu, Abraham Maslow menetap hingga memanfaatkan tahun akhirnya pada California City hingga pada tanggal 8 Juni 1970, Abraham Harold Maslow wafat dikarenakan penyakit Jantung kronis yang sempat dideritanya. Abraham Harold Maslow ialah pioner pada bidang ilmu psikologis. Sebutannya humanistik psikologis yaitu sebutan yang sekarang ini diciptakan dari Abraham Harold Maslow bagi dirinya diawali dari caranya memberi pemahaman atas pemikiran pada manusia, berdasarkan penjelasan yang telah dipaparkan, Abraham 
Maslow membagi kebutuhan humanis dalam berbagai jenjang, yaitu: (Abraham Maslow, 1993)

1. Keperluan Fisiologis

2. Keperluan Keamanan

3. Keperluan Sosial

4. Aktualisasi diri

Teori Kebutuhan Maslow dalam Pembelajaran PAI SD diuraikan sebagai berikut:

1. Kebutuhan Fisiologis

Kebutuhan fisiologis yakni keperluan yang paling dasar dari manusia sebagai cara untuk bertahankan hidup baik dari segi fisik, yaitu kebutuhan untuk makan dan minum, tempat untuk tinggal, seksual, udara bernapas, istirahat, maupun tidur. Bagi masyarakat yang makmur, biasanya kebutuhan fisiknya sudah terpenuhi. Apabila kebutuhan dasar telah terpenuhi, maka kebutuhan-kebutuhan lainnya yang tingkatannya lebih tinggi akan bermunculan serta memberi dominasi pada tindakan manusia. (Frank, 1995). Hal ini menunjukkan bahwasanya motivasi yang paling tinggi merupakan keperluan fisiologis dalam memberi motivasi peserta didik, yaitu makanan solusinya, hasil analisis tentang kebutuhan fisiologis menurut hasil penelitian Wiresti (2020) sinta 2 yakni otak yang berkembang dalam anak berusia dasar sangat memberi pengaruh perkembangan kognitif anaknya. Maka, orang tua perlu memberi perhatian dalam asupan minuman maupun makanan anaknya.

Dalam pembelajaran PAI, memberi perhatian yang mendalam dalam pengajaran suatu keilmuan serta metode yang sesuai bisa lebih memotivasi peserta didik daripada nasihat pengajarnya. Terdapat beragam aktivitas dalam memenuhi keperluan fisiologis di pengajaran PAI, yang merupakan usaha dalam memenuhi keperluan dasar peserta didik dalam pemebelajaran PAI antara lain: mencintai PAI dalam proses pembelajaran, ini mengartikan bahwa diharuskan untuk di dorong dengan faktor-faktor seperti pendidik yang berkompeten, bahan ajar atau materi yang sangat menarik, serta metode atau model mengajar yang diterapkan tidak membosankan peserta didik, missalnya dengan cara menonton tayangan film terkait kisah-kisah Nabi serta para sahabat-sahabatnya.

\section{Kebutuhan Rasa Aman}

Hasil penelitiannya Inikah (2015) sinta 2 yakni kepribadian anak tercipta melalui pola asuhnya dari orang tua terhadap anaknya. Dalam memenuhi kebutuhan terkait keamanan tidak bisa dilepaskan dari peranan orang tua supaya anak mendapatkan rasa tentram, pasti, serta lingkungan yang teratur. Sedangkan dari hasil penelitian Tekeng dan Alsa (2016) sinta 2 lebih memberi penekana n kepada pendidik yang mengimplementasikan pengajaran berdemokratis, siswa mempu-nyai peluang dalam menyampaikan pendapatnya di kondisi yang membuat senang supaya siswa tidak merasakan ketakutan disalahkan gurunya ataupun dari siswa lain.

Pemenuhan akan rasa aman dalam proses belajar mengajar di perlukan kemampuan guru dalam mengkontrol suasana di dalam kelas yang aman, nyaman, dan kondusif pada saat proses pembelajaran dilaksanakan pada kelasnya. Di pengajaran PAI pendidik lebih sering memberi pujian atau rewards berdasarkan seluruh tindakan siswanya maupun memberi hukumgan terhadap tindakan tidak siswa dari siswa. Seperti, pendidik memberi penguatan reward dan verbal untuk peserta didik yang bisa melaksanakan tugas secara maksimal yang telah diberikan oleh guru, seni mengajar PAI ialah suatu kegiatan pendidik yang harus dilaksanakan melalui kemampuan, pemahaman, serta cara pengajaran gurunnya dalam mempersia-pkan siswanya di keadaan siap serta optimal maka dapat terciptanya kondisi pembelajaran dengan keamanan, kenyamanan, keefektifan, serta kefisiensian.

3. Kebutuhan Sosial

Faktor yang begitu membawa pengaruhnya mengenai kesuksesan dalam tahapan pengajaran ialah lingkungan sosial, tanpa kecuali pada pembelajaran PAI di Sekolah Dasar. Stephen D. Krasen kemudian menyebutkan yakni implementtasi lingkungan PAI bisa memiliki keefektifan dibandingkan mempergunakan metode berinovasi. Halnya ini memberi indikasi yakni lingkungan sebagai faktor penting yang memberi pengaruh keterampilan pembelajarna, lingkungan-nya ini pun 
memberi pengaruhnya langsung kepada siswa untuk mengimplementasikan teori yang dipelajari di kelasnya. (Nur Habibah, 2016)

4. Kebutuhan Akan Aktualisasi Diri

Aktualisasi diri (self actualitation) merupakan ingkatan kebutuhan paling tertinggi dan akan dipenuhi sesudah seluruh kebutuhannya yang lain telah dipenuhinya. Keperluan ini adalah keperluan untuk memenuhi kepribadian yakni bakat serta potensi yang dikuasainya melaui pengoptimalan keterampilan agar jadi manusia dengan keunggulan yang baik (Mahrus \& Itqon, 2020). Tanda apabila keperluan dalam mengaktualisasikan diri telah dipenuhi yakni apabila rasa nyaman serta penghargaan dijadikan keterpaduan untuk suatu motivasi sreta fokus dalam permasalahan tertentu agar melanjutkan kehidupannya, memberi perhatian partumbuhan diri, serta keterampilan meraih tujuannya, dan mempunyai wawasan mengenai karirnya (Utamaningsih, Monika, \& Yenida, 2019).

Tiap orang perlu bisa mengembangkan dengan sepenuhnya atas kemampuan dirinya. Keperluan mansuia dalam tumbuh kembangnya, serta mempergunakan keterampilan disebutkan Maslow merupakan pengaktualisasian diri. Berdasarkan Maslow pun mengaktualisasikan diri yakni hasrat agar semakin jadi diri dengan sepenuhnya atas kemampuannya, jadi individu yang berdasarkan kemampuannya. Keperluan dalam mengaktualisasikan diri ini umumnya timbul jika kebutuhannya akan cinta serta penghargaan sudah diperoleh dengan mumpuni.(Frank, 1992)

Hasil penelitiannya Mahrus \& Itqon pada jurnal sinta 2,4 , dan 5 , pemberian motivasi pada anak sebagai pembuktian serta menandaan seluruh keterampilan, kapasitasnya, serta potesninya terhadap individu lainnnya sebagai cara untuk memenuhi keperluan akan aktualisasi diri ini, dalam proses pembelajaran PAI di SD, guru hendaknya memperhatikan kondisi peserta didik, pada makna yakni tugas pendidik tidak sekadar memberi ilmu pengetahuan, namun pula untuk fasilitator dam membimbing siswanya dalam pembelajaran PAI. Kegiatan di dalam kelas sebagai induknya atas penyelenggaraan kependidikan forman namun guru ada tuntutan agar bisa mengelola kelas dengan baik, penggunaan metode maupun media belajar yang berkaitan dengan karakteristik siswa-siswanya, dan aktualisasi dirinya siswa supaya bisa berinteraksi dalam pembelajaran PAI.

\section{SIMPULAN DAN SARAN}

\section{A. Simpulan}

Berdasarkan hasil dari analisis artikel jurnal sinta 2 sampai sinta 6 bisa berkesimpulan yakni pada pengajaran PAI dalam SD sangan diperlukan suatu pendekatan yang tepat dalam implementasi pembelajarannya, karena Pendidikan Agama Islam merupakan pembelajaran yang mempunyai sifat spesifik terhadap tingkatan kesukaran yang cenderung tinggi maka sangat berpotensi bagi peserta didik untuk mengalami kejenuhan dan kebosanan dalam proses pembelajaran. Berdasarkan kaitannya dengan siswa, pendekatan humanistik ini berusaha untuk mengakomodasikan beragam kebutuhannya siswa di pengajaran Pendidikan Agama Islam menggunakan pendekatan yang lebih mengarahkan siswa maupun pengajarannya yang meiliki arti yang dihubungkan terhadap pengalaman belajarnya siswa-siswa..

Abraham Maslow merupakan seorang psikolog humanis, yang sudaah melahirkan teori keperluan dengan mengaktualisasikan diri menjadi keutamaannya. Proses pelaksanaan pada pengajaran Pendidikan Agama Islam disediakan berdasarkan dengan kebutuhan siswa dari yang mendasar sampai kebutuhannya yang paling tinggi di hubungannya terhadap keberadaan manusia tersebut, sehingga harus dibutuhkan model pengajaran yang berinovatif, berkreatif, serta membuat senang supaya siswanya merasa adanya makna dalam proses belajar menngajar Pendidikan Agama Islam di Sekolah Dasar.

Pelaksanaan dari teori belajar humanistic ini lebih mempunyai fokus terhadap motivasi selama proses belajar menagajar. Tugas tenaga pendidik dalam proses belajar humanistik yaitu jadi pihak yang memfasilitasi peserta didik di SD, pendidik memberi semangatnya, rasa sadar terkait makna pembelajaran dalam kehidupan siswa. Tenaga pendidik memberikan pengalaman belajar terhadap siswa, dan mendampinginya guna mencapai tjuan dari pembelajaran. Peserta didik berfungsi sebagai pelaku utama (student 
center) yang mengartikan proses dalam mendapatkan pengalaman pembelajarannya, aspek dalam tercapainya penerapan teori humanistic ialah perasaan menyenangkan dan tidak adanya keterpaksaan yang dialami siswa. Dalam hal ini peserta disik bukan memiliki inisiatif sendiri komponen pembelajaran. Pola berpikir, sifatnya, maupun sikapnya, melaksanakan keinginan tersendiri dan tidak dalam keadaan terkekan.

\section{B. Saran}

Adapun saran yang dapat disampaikan peneliti untuk penelitian selanjutnya ialah diharapkan lebih banyak menggunakan artikel atau jurnal terkait dan hasil literature riview ini diharapkan bis menjadi acuan ataupun referensi bagi peneliti selanjutnya dalam melakukan penelitian mengenai teori humanistik kebutuhan maslow sehingga dapat menambah wawasan dan pengetahuan yang lebih lagi.

\section{DAFTAR RUJUKAN}

Abbas, J. (2020). Service Quality in Higher Education Institutions: Qualitative Evidence from the Studentss Perspective using Maslow Hierarchy of Needs. International Journal of Quality and Service Sciences, 12(3), 371-384.

Alaudin, "Prinsip dan Implikasi Teori Belajar Humanistik Dalam Pembelajaran", Jurnal Pendidikan IQRA, 3 (1), 2015.

Amalia, Aam. "Aplikasi Teori Kebutuhan Maslow dalam Pembelajaran Bahasa Arab (Implementasi Humanistik)". Jurnal Edulab 4 (2) , 2019.

Arbayah, Model Pembelajaran Humanistik. Dinamika Ilmu: (Jurnal Pendidikan), 2013.

Erl W. Stevick. 1991. Humanism in Language Teaching. New York: Oxford University Press

Goble, Frank, Mazhab Ketiga, Psikologi Humanistik Abraham Maslow, Yogyakarta: Kanisius,1992.

Habibah, Nur, Lingkungan Artifisial dalam Pembelajaran Bahasa Arab, Jurnal Arabiyat, 3 (2), Desember 2016. http://en.wikipedia.org/wiki/Abraham Mas low, (30 Maret 2019) http://repository.umy.ac.id/ (1 April 2019)

https://dosenpsikologi.com/teori-kebutuhanmaslow, (1 April 2019)

Ifeldi, C. J. (2012). Perception on Maslow Hierarchy of Need Theory by Nigerian University Workers a Challenge to University Administrators. Interdisiplinery Journal of Contemporary Research in Business. 4, 79-85

Mahrus, \& Itqon, Z.. Implikasi Teori Humanistik dan Kecerdasan Gaanda dalam Desain Pembelajaran PAI. PIWULANG: Jurnal Pendidikan Agama Islam, 3 (1), 2020.

Maslow, Abraham, Motivasi dan Kepribadian, alih bahasa: Nurul Iman, Bandung: Rosyda Karya 1993.

Namiroh, Lubis. "Peran Teori Hirarki Kebutuhan Abraham Maslow Dalam Pembelajaran IPA Kelas IV"Jurnal Pesona Dasar 5 (2),2017.

Riyanton, Muhammad, Pendidikan Humanisme dan Implementasinya dalam Pembelajaran Bahasa Indonesia. Jurnal Lingua Idea, 6 (1), 2015.

Roberts, T. B. (1975). Four Psychologies Applied to Education: Freudian, Behavorial, Humanistic, Transpersonal. New York: Schenkman Pub. Co

Sengupta Singh Sunita, Growth in Human Motivation: Beyond Maslow, Indian Journal of Industrial Relations, Vol.47, No.1 (July 2011), pp 102-116

Soemanto, Wasty, Psikologi Pendidikan, Jakarta: Bina Aksara, 1987.

Sumantri, Budi. "Teori Belajar Humanistik Dan Implikasinya Terhadap Pembelajaran Pendidikan Agama Islam". Fondatia: Jurnal Pendidikan Dasar, 3 (2), 2019.

Suprihatinin, Pendekatan Humanistik Dalam Pengembangan Kurikulum Pendidikan Agama Islam, Vol. 3, No.1, Januari-Juni 2017.

Yasin, Muhammad. "Teori Humanistik dalam Pe mbelajaran". Jurnal: An-Nur, 1 (1), 2017. 